\title{
The content of chosen chemical elements in wool of sheep of different origins and breeds
}

\author{
BOŻENA PATKOWSKA-SOKOŁA ${ }^{1}$, ZBIGNIEW DOBRZAŃSKI ${ }^{1}$, KHALIL OSMAN² ${ }^{2}$ ROBERT \\ BODKOWSKI ${ }^{1}$ and KATARZYNA ZYGADLIK ${ }^{1}$
}

${ }^{1}$ Faculty of Biology and Animal Husbandry, Wrocław University of Environmental and Life Sciences, Wroclaw, Poland, ${ }^{2}$ Faculty of Veterinary Medicine, Al-Baath University in Homs, Syria

\section{Abstract}

The following chemical elements in sheep wool originating from Poland (Polish Mountain Sheep), Greece (Karagounico breed), and Syria (Awassi breed) were analysed: macroelements $(\mathrm{Ca}, \mathrm{P}, \mathrm{Na}, \mathrm{K}, \mathrm{Mg}, \mathrm{S})$, trace elements (Al, Ba, $\mathrm{Co}, \mathrm{Cu}, \mathrm{Fe}, \mathrm{Mn}, \mathrm{Mo}, \mathrm{Sr}, \mathrm{Ti}, \mathrm{Zn}$ ) and heavy metals (As, $\mathrm{Cd} \mathrm{Hg}, \mathrm{Pb}$ ). Some statistically significant differences were observed between the content of the examined elements in sheep wool collected in the above countries. Sulphur, calcium, sodium and potassium were found in the highest amounts, while arsenic, cadmium and mercury occurred in the lowest quantity.

Keywords: sheep, wool, chemical elements, Poland, Greece, Syria

\section{Zusammenfassung}

\section{Der Gehalt ausgewählter chemischer Elemente in Schafwollen unterschiedlicher Herkunft und Rasse}

Für die Untersuchung standen Schafwollen aus Polen (Polnisches Bergschaf), Griechenland (Karagounischaf) und Syrien (Awassischaf) zur Verfügung. Untersucht wurden ausgewählte Makroelemente ( $\mathrm{Ca}, \mathrm{P}, \mathrm{Na}, \mathrm{K}, \mathrm{Mg}, \mathrm{S})$, Spurenelemente (Al, $\mathrm{Ba}, \mathrm{Co}, \mathrm{Cu}$, $\mathrm{Fe}, \mathrm{Mn}, \mathrm{Mo}, \mathrm{Sr}, \mathrm{Ti}, \mathrm{Zn}$ ) und Schwermetalle ( $\mathrm{As}, \mathrm{Cd}, \mathrm{Hg}, \mathrm{Pb}$ ). Bei den Makroelementen $\mathrm{Ca}, \mathrm{P}$, $\mathrm{Na}, \mathrm{Mg}$ und $\mathrm{S}$ bestanden signifikante Unterschiede zwischen den Länderpopulationen. Hervorzuheben ist der Mg Gehalt, dessen Wert in Syrien den polnischen Wert um das Fünffache übersteigt. Auch die Werte für die Spurenelemente differierten zwischen den Populationen signifikant. Die Werte der syrischen Wolle waren charakterisiert durch hohe Gehalte an Al, Fe, Ti und As. Bei den Schwermetallen unterschieden sich die Gehalte an As und $\mathrm{Hg}$ zwischen den Populationen. Eine Interpretation der Gehaltsunterschiede ist schwierig und nur bei Einbeziehung von Analysenwerten von Mineralgehalten in Böden Futter und Wasser möglich.

Schlüsselwörter: Schaf, Wolle, chemische Elemente, Polen, Griechenland, Syrien

\section{Introduction}

Sheep fleece, similar to other animals' coats, presents a specific chemical indicator, and a concentration of the elements it contains reflects both feed and nutrition quality, as well as climate and the state of the environment. It is obvious that many other factors, such as 
breed, sex, age, physiological and health state (RAMIREZ-PEREZ et al. 2000), can modify the chemical composition of wool and coats. For instance, HUANG and CHEN (2001) report that in the wool of sheep and goats suffering from fleece-eating (Shimao Zheng) higher concentrations of $\mathrm{Ca}, \mathrm{P}, \mathrm{Fe}, \mathrm{Mn}, \mathrm{Zn}, \mathrm{Cu}, \mathrm{Co}, \mathrm{Se}, \mathrm{F}$ can be observed, while $\mathrm{S}$ and $\mathrm{Mo}$ are present in lower concentrations. GABRYSZUK et al. (2000) note some significant differences between $\mathrm{Ca}, \mathrm{Mg}, \mathrm{K}, \mathrm{Zn}$ and Fe concentrations in Booroola and Polish Merino sheep wool. In the case of Merino sheep significant differences for $\mathrm{Ca}, \mathrm{Mg}$ and $\mathrm{Zn}$ content were found between the perinatal period and the periods of resting and tupping.

Investigations by KROŚNICKA-BOMBAŁA (1996) prove that pigment content in sheep and goat coats affects the accumulation of certain elements. The author identified positive correlations between eumelanine content and $\mathrm{Fe}, \mathrm{Cu}, \mathrm{Mn}, \mathrm{K}, \mathrm{Na}$ and $\mathrm{Mg}$ concentration. ŻARSKI (1988) reported variable contents of $\mathrm{Ca}, \mathrm{Na}, \mathrm{K}, \mathrm{Mg}, \mathrm{Fe}, \mathrm{Zn}, \mathrm{Mn}$ and $\mathrm{Cu}$ in the hair of cattle and roe deer from different regions of Poland depending on the richness in those elements of soil and plants, and GALLO et al. (1996) about the relationship of minerals in soil, plants and animal tissues. Moreover, ŻARSKI (1988) confirmed statistically significant correlations between $\mathrm{Na}, \mathrm{Mg}, \mathrm{Fe}$, and $\mathrm{Zn}$ content in the liver and hair of roe deer. The use of salt licks with zinc content did not cause any fundamental changes in the chemical content (with the exception of $Z n$ ) of these animals' hair. SZTYCH and SOROCZYŃSKA (1994) report about stages of lactation related to macroand microelements in wool of sheep. A number of authors describe mineral components in the blood of sheep as indicators in connection to genotype, age, lactation, reproductive status or soil and environment (GALLO et al. 1996, CASTILLO et al. 1997, BARANOWSKI 2002, ANTUNOVIC et al. 2004, BARANOWSKI et al. 2004).

However, hair is considered to be a good bioindicator of the state of the environment, soil, water and air pollution, even better than blood, urine or animal milk.

ENNE et al. (1989) reported high concentrations of toxic metals $(\mathrm{Cd}, \mathrm{Cu}, \mathrm{Pb}, \mathrm{Zn})$ in sheep wool from mining regions in Italy, while KOŁACZ et al. (1999) observed significantly higher concentrations of $\mathrm{As}, \mathrm{Ba}, \mathrm{Cd}, \mathrm{Co}, \mathrm{Fe}, \mathrm{Mn}, \mathrm{Mo}, \mathrm{Pb}, \mathrm{S}, \mathrm{Ti}$ and $\mathrm{Zn}$ in the case of sheep from areas under the influence of the copper industry in comparison to ecologically clean regions. PATKOWSKA-SOKOŁA et al. (2003), in research on Merino sheep from the National Reserve Park in Poland, detected significantly higher concentrations of $\mathrm{Ba}, \mathrm{K}, \mathrm{Na}$ and significantly lower ones of $\mathrm{Cd}, \mathrm{Co}, \mathrm{Cu}, \mathrm{Fe}, \mathrm{Mn}, \mathrm{Mo}, \mathrm{Si}, \mathrm{Ti}$ and $\mathrm{Zn}$ as compared to similar sheep breeds from the Mesaria Lowland in Cyprus.

The aim of the present work is an assessment of chemical element composition in wool from sheep of similar performance types, but originating from three different countries: Poland, Greece and Syria.

\section{Material and methods}

The research material was obtained from 3-year-old sheep mothers of a similar performance type (meat-milk) and the same type of coat (mixed wool). The samples were collected in the late summer period when the sheep were in pastures. Sheep were typical for their region of origin. 
The Polish material (W-PI) involved sheep of the Polish Mountain Sheep breed. Those animals can be found across the whole Polish Carpathian region; however, most commonly in Podhale in the region of Nowy Sącz where the collection of samples took place. In Greece, samples (W-Gr) were obtained from the Karagounico sheep breed from the Thessaloniki region. Those sheep are the most characteristic for the lowlands of western Thessaly. The material from Syria (W-Sy) was wool samples from the Awassi sheep breed, commonly occurring in that country, collected in Syria central province of Homs.

Wool samples weighing 12-20 g were collected by cutting them out from the left and right sides of 10 animals representing each of three countries. Then the samples were subjected to cleaning and degreasing processes. Foreign substances and plant parts were separated prior to washing in warm water $\left(50^{\circ} \mathrm{C}\right)$ with detergent. Samples were rinsed twice in distilled water, and then left for natural drying. Samples thus prepared were then subjected to chemical analysis after they had been mineralized using the MARS-5 (CEM, USA) microwave system. 100-fold diluted nitric acid (MERCK, Germany) solution was applied. The weight of analytical samples was $0.5 \mathrm{~g}$. A VARIAN LIBERTY type 220 (USA) spectrophotometer was used for analysis. Mercury concentration was determined by a direct method using an analyzer of MA 200 type (NIC Japan). The weight of analytical samples ranged from 100 to $200 \mathrm{mg}$. In wool samples 6 macroelements ( $\mathrm{Ca}, \mathrm{P}, \mathrm{Na}, \mathrm{K}, \mathrm{Mg}, \mathrm{S}), 10$ trace elements ( $\mathrm{Al}, \mathrm{Ba}, \mathrm{Co}$, $\mathrm{Cu}, \mathrm{Fe}, \mathrm{Mn}, \mathrm{Mo}, \mathrm{Sr}, \mathrm{Ti}, \mathrm{Zn}$ ) and 4 heavy metals ( $\mathrm{As}, \mathrm{Cd}, \mathrm{Hg}, \mathrm{Pb}$ ) were analysed.

Analytical analyses were conducted in the Analytical Laboratory of Wrocław University of Environmental and Life Sciences. The results obtained were statistically analysed using the Duncan test to calculate mean values, standard deviations, significance of differences between the groups on Statistica 7.1 software.

\section{Results and discussion}

The results of the analyses were presented in tabular format taking into account the division into macroelements, trace elements and heavy metals. All of them, regarding percentage weight, provided for $2.736 \%$ in the wool from Greece (W-Gr), $2.649 \%$ from Poland (W-PI), and $2.522 \%$ from Syria (W-Sy).

\section{Macroelements}

Table 1 shows the results of the analysis of the main macroelements. Calcium (Ca) content ranged from 1790 to $2900 \mathrm{mg} / \mathrm{kg}$. The highest amount of Ca was found in the case of $W-G r$, while the lowest one in W-PI (differences significant statistically, $P<0.05$ ). Some authors (KROŚNICKA-BOMBAŁA 1996, GABRYSZUK et al. 2000) report the range of this basic macroelement in sheep wool from 645.6 to $1720.6 \mathrm{mg} / \mathrm{kg}$, although in the case of ill sheep even an amount of $0.44 \%(4400 \mathrm{mg} / \mathrm{kg}$ ) (HUANG and CHEN 2001) was detected. Amount of Ca determined by AYDIN (2008) in wool from male lambs collected in Turkey was on a level of $0.41-0.57 \%$.

Phosphorus (P) concentration ranged from 148 to $284 \mathrm{mg} / \mathrm{kg}$. Its highest values were recorded in W-Sy and the lowest content in the case of W-PI $(P<0.05)$. Some authors (HUANG and CHEN 2001) determine a similar range of this important bioelement concentration, i.e. from 163 to $300 \mathrm{mg} / \mathrm{kg}$. 
Table 1

Content of marcoelements in sheep wool from Poland, Greece and Syria $(\mathrm{mg} / \mathrm{kg})$

Gehalt an Makroelementen in Schafwollen aus Polen, Griechenland und Syrien $(\mathrm{mg} / \mathrm{kg})$

\begin{tabular}{lrrrr}
\hline Element & \multicolumn{1}{c}{ Poland } & \multicolumn{1}{c}{ Greece } & \multicolumn{1}{c}{ Syria } \\
\hline Calcium (Ca) & $1790.0^{\mathrm{a}} \pm 392.0$ & $2900.0^{\mathrm{b}} \pm 591.0$ & $1800.0^{\mathrm{a}} \pm 351.0$ \\
Phosphorus (P) & $148.0^{\mathrm{a}} \pm 32.3$ & $206.0^{\mathrm{b}} \pm 49.2$ & $284.0^{\mathrm{c}} \pm 59.8$ \\
Sodium (Na) & $1486.7^{\mathrm{a}} \pm 234.2$ & $2165.0^{\mathrm{b}} \pm 573.1$ & $1745.5 \pm 1152.6$ \\
Potassium (K) & $718.6^{\mathrm{a}} \pm 307.7$ & $643.0^{\mathrm{b}} \pm 312.9$ & $755.0^{\mathrm{a}} \pm 295.3$ \\
Magnesium (Mg) & $120.8^{\mathrm{a}} \pm 17.2$ & $383.5^{\mathrm{b}} \pm 65.4$ & $590.8^{\mathrm{c}} \pm 133.5$ \\
Sulphur (S) & $22038.3^{\mathrm{a}} \pm 663.9$ & $20758.0^{\mathrm{b}} \pm 947.5$ & $18733.4^{\mathrm{c}} \pm 1212.4$ \\
\hline
\end{tabular}

$\mathrm{a}, \mathrm{b}, \mathrm{c} P<0.05$

The concentration of sodium ( $\mathrm{Na}$ ) ranged from 1486.7 to $2165 \mathrm{mg} / \mathrm{kg}$. The highest amount of this element was observed in the case of W-Gr, while the lowest in W-PI $(P<0.05)$. Some authors (KROŚNICKA-BOMBAŁA 1996, PATKOWSKA-SOKOŁA et al. 2003) report a very wide range of $\mathrm{Na}$ concentrations, i.e. $172.2-1463.5 \mathrm{mg} / \mathrm{kg}$, while AYDIN (2008) reports a content of that element on a level of $0.28-0.36 \%$.

Potassium (K) concentration ranged from 643 to $755 \mathrm{mg} / \mathrm{kg}$. Its highest amount was observed in the case of W-Sy, while the lowest one in W-Gr, although the differences were not significant statistically. Certain authors (KROŚNICKA-BOMBAŁA 1996, GABRYSZUK et al. 2000, PATKOWSKA-SOKOŁA et al. 2003, AYDIN 2008) report a relatively wide range of potassium concentrations, i.e. from 204 to $2499.2 \mathrm{mg} / \mathrm{kg}$.

The determined magnesium $(\mathrm{Mg})$ content was within the range of 120.8 to 590.8 $\mathrm{mg} / \mathrm{kg}$. The highest values were noted in the case of W-Sy, and the lowest ones in W-PI $(P<0.05)$. Some authors (KROŚNICKA-BOMBAŁA 1996, GABRYSZUK et al. 2000) report quite a wide $\mathrm{Mg}$ concentration range in sheep hair, i.e. $47.8-263.4 \mathrm{mg} / \mathrm{kg}$, while AYDIN (2008) found a content of that element ranged from $0.09-0.13 \%$ in wool from male lambs.

Sulphur (S) concentration varied within the range of 18733.4 to $22038.3 \mathrm{mg} / \mathrm{kg}$. It was the highest in the case of W-PL, and the lowest in W-Sy $(P<0.05)$. PATKOWSKA-SOKO $Ł A$ (1990) determined sulphur concentration in Merino sheep wool at a level of 2.90-3.28\%, depending on its supply in animal diet and the season of the year, while other authors (GEORGIEVSKI et al. 1982, HUANG and CHEN 2001) generally report its values from $2.61 \%$ to as much as $4 \%$ (4000 ppm).

\section{Trace elements}

Table 2 presents the results of the analysis of the main microelements. Aluminium (Al) concentration in sheep wool collected in the three countries varied within a wide range of 53.65 to $620.83 \mathrm{mg} / \mathrm{kg}$. The highest amount was found in W-Sy, and the lowest one in W-PI $(P<0.05)$.

The observed concentration of barium $(\mathrm{Ba})$ ranged from 1.56 to $9.42 \mathrm{mg} / \mathrm{kg}$. The highest amount of this element was found in the case of W-Sy, while the lowest in W-PI $(p<0.05)$. Some authors (KOŁACZ et al. 1999, PATKOWSKA-SOKOŁA et al. 2003) give a short range of barium content in wool from sheep from different habitats, i.e. 2.146-4.687 $\mathrm{mg} / \mathrm{kg}$. Generally, in the case of terrestrial animals the concentration of this toxic element is quite low, in soft tissues it is $0.1-2.5$ and in bones $5-30$ ppm of dry matter (KABATAPENDIAS and PENDIAS 1999). 
Table 2

Content of trace elements in sheep wool from Poland, Greece and Syria $(\mathrm{mg} / \mathrm{kg})$

Gehalt an Spurenelementen in Schafwollen ( $\mathrm{mg} / \mathrm{kg}$ )

\begin{tabular}{lrrrr}
\hline Element & \multicolumn{2}{c}{ Poland } & Greece & \multicolumn{2}{c}{ Syria } \\
\hline Aluminium (Al) & $53.65^{\mathrm{a}} \pm 5.46$ & $127.00^{\mathrm{b}} \pm 24.58$ & $620.83^{\mathrm{c}} \pm 304.51$ \\
Barium (Ba) & $1.56^{\mathrm{a}} \pm 0.33$ & $3.67^{\mathrm{b}} \pm 0.9$ & $9.42^{\mathrm{c}} \pm 2.94$ \\
Cobalt (Co) & $0.98^{\mathrm{a}} \pm 0.31$ & $0.65^{\mathrm{a}} \pm 0.24$ & $2.31^{\mathrm{b}} \pm 1.25$ \\
Copper (Cu) & $5.30^{\mathrm{a}} \pm 1.86$ & $6.79^{\mathrm{a}} \pm 1.33$ & $10.30^{\mathrm{b}} \pm 3.09$ \\
Iron (Fe) & $22.03^{\mathrm{a}} \pm 3.55$ & $76.70^{\mathrm{b}} \pm 27.37$ & $513.17^{\mathrm{c}} \pm 201.79$ \\
Manganese (Mn) & $3.37^{\mathrm{a}} \pm 1.65$ & $4.43^{\mathrm{a}} \pm 1.8$ & $22.93^{\mathrm{b}} \pm 13.93$ \\
Molybdenum (Mo) & $1.02^{\mathrm{a}} \pm 0.27$ & $0.91 \pm 0.18$ & $0.77^{\mathrm{b}} \pm 0.19$ \\
Strontium (Sr) & $2.83^{\mathrm{a}} \pm 0.52$ & $8.46^{\mathrm{b}} \pm 1.43$ & $14.07^{\mathrm{c}} \pm 1.52$ \\
Titanium (Ti) & $0.54^{\mathrm{a}} \pm 0.29$ & $3.54^{\mathrm{b}} \pm 1.57$ & $40.47^{\mathrm{c}} \pm 18.32$ \\
Zinc (Zn) & $88.80^{\mathrm{a}} \pm 5.45$ & $75.02^{\mathrm{b}} \pm 3.88$ & $73.62^{\mathrm{b}} \pm 9.16$ \\
\hline
\end{tabular}

$\mathrm{a}, \mathrm{b}, \mathrm{c} P<0.05$

Cobalt (Co) content ranged from 0.65 to $2.31 \mathrm{mg} / \mathrm{kg}$. The highest amount was in the case of W-Sy, and the lowest in W-Gr $(P<0.05)$. The authors (KOŁACZ et al. 1999, PATKOWSKASOKOŁA et al. 2003) report Co range from 0.0186 to $0.1873 \mathrm{mg} / \mathrm{kg}$, depending on the degree of environmental pollution or the country of origin. However, in the case of healthy sheep and goats in China quite low Co content values, i.e. 0.054 ppm on average, were recorded (HUANG and CHEN 2001), while AYDIN (2008) reports the content of Co in the case of male lambs in Turkey on a level of $0.59-1.36 \mathrm{mg} / \mathrm{kg}$.

Copper $(\mathrm{Cu})$ concentration ranged from 5.30 to $10.30 \mathrm{mg} / \mathrm{kg}$. The highest values were found for W-Sy, while the lowest ones for W-PI $(P<0.05)$. Research by numerous authors (ENNE et al. 1989, SCOTT 1991, KOŁACZ et al. 1999, PATKOWSKA-SOKOŁA et al. 2003, AYDIN, 2008) prove that copper concentration in sheep wool covers a wide range from 1.70 to $25 \mathrm{mg} / \mathrm{kg}$. RAMIREZ-PEREZ et al. (2000) report that, to a large degree, it depends on its concentration in animal diet. Low $\mathrm{Cu}$ level in blood can affect its diminished content in wool.

Iron (Fe) concentration varied within the range of 22.03 to $513.17 \mathrm{mg} / \mathrm{kg}$. The highest content of this element was observed in the case of W-Sy, while the lowest in W-PI $(P<0.05)$. Numerous authors (WÓJCIKOWSKA and SZTYCH 1994, KOŁACZ et al. 1999, RAMIREZ-PEREZ et al. 2000, PATKOWSKA-SOKOŁA et al. 2003) report a wide range of this element concentration, from 2.56 to $52.6 \mathrm{mg} / \mathrm{kg}$. To a large degree it depends on this element's content in soil as well as in the feed that sheep intake while grazing. Very high values in sheep wool in China (365.4-788.5 mg/kg) were reported by HUANG and CHEN (2001), and in wool from lamb in Turkey (106.07-120.52 mg/ kg) as reported by AYDIN (2008).

The observed manganese $(\mathrm{Mn})$ concentration ranged from 3.37 to $22.93 \mathrm{mg} / \mathrm{kg}$. The highest values were noted in the case of W-Sy, while the lowest ones in W-PI $(P<0.05)$. Some authors (GEORGIEVSKI et al. 1982, KROŚNICKA-BOMBAŁA 1996, HUANG and CHEN 2001, PATKOWSKA-SOKO ŁA et al. 2003, AYDIN, 2008) report Mn content ranged from 0.35 to $20 \mathrm{mg} / \mathrm{kg}$, depending on the state of the environment and the animal's origin.

Molybdenum (Mo) concentration ranged from 0.77 to $1.02 \mathrm{mg} / \mathrm{kg}$. Its highest content was observed in W-PI, while the lowest in W-Sy $(P<0.05)$. Some authors (KOŁACZ et al. 1999, HUANG and CHEN 2001, PATKOWSKA-SOKOŁA et al. 2003) determined the molybdenum concentration at a level from 0.048 to $0.372 \mathrm{mg} / \mathrm{kg}$. In terrestrial animal muscles this 
element occurs in low concentrations ranging from 0.02 to $0.05 \mathrm{ppm}$, and in bones from 0.5 to $1 \mathrm{ppm}$ in dry matter. Its availability in ruminants depends on $\mathrm{Cu} / \mathrm{Mo}$ ratio in feed (KABATA-PENDIAS and PENDIAS 1999).

Strontium (Sr) content ranged from 2.83 to $14.07 \mathrm{mg} / \mathrm{kg}$. The highest content of this element was noted in the case of W-Sy, while the lowest in W-PI $(P<0.05)$. The authors (KOŁACZ et al. 1999, PATKOWSKA-SOKOŁA et al. 2003) report similar values of this element $(8.044-9.303 \mathrm{mg} / \mathrm{kg})$ for sheep originating from different environments. Strontium accumulates mainly in hard tissues (30-100 ppm DM [dry matter]) and it takes part in Ca metabolism (PORS NIELSEN 2004).

Titanium (Ti) content ranged from 0.54 to $40.47 \mathrm{mg} / \mathrm{kg}$. The highest values were noted for W-Sy, and the lowest ones for W-PI. The authors (KOŁACZ et al. 1999, PATKOWSKASOKOŁA et al. 2003) determined Ti concentration at a level from 0.64 to $2.35 \mathrm{mg} / \mathrm{kg}$. There is not much published literature concerning this element. It is known that titanium accumulates in animal muscles in the amount of $0.5-2.0 \mathrm{ppm} \mathrm{DM}$, and in bones at a level of $1.5 \mathrm{ppm}$ DM; however, its role has not been sufficiently recognized so far (KABATAPENDIAS and PENDIAS 1999).

Zinc (Zn) content ranged from 73.62 to $88.80 \mathrm{mg} / \mathrm{kg}$. The highest values were observed in the case of W-PI, while the lowest in W-Sy $(P<0.05)$. Authors (GEORGIEVSKI et al. 1982, ENNE et al. 1989, KOŁACZ et al. 1999, HUANG and CHEN 2001, PATKOWSKA-SOKOŁA et al. 2003, AYDIN 2008) reported a wide range of this bioelement concentration, ranged from 18.3 to $336.9 \mathrm{mg} / \mathrm{kg}$. According to SCOTT (1991), a normal Zn content in sheep wool ranges from 35 to $195 \mathrm{mg} / \mathrm{kg}$, depending mainly on its supply in animal diet and the physiological state of sheep. RAMIREZ-PEREZ et al. (2000) proved significant differences in this element content between the Rambouillet and Suffolk ewes' wool.

\section{Heavy metals}

Table 3 shows the results of the main heavy metals analysis. The observed arsenic (As) content was within the range of 0.206 to $0.765 \mathrm{mg} / \mathrm{kg}$. The highest values were found in the case of W-Sy, while the lowest ones in W-Gr $(P<0.05)$. Some authors (KOŁACZ et al. 1999, BODKOWSKI et al. 2006) report a concentration range from 0.029 to $0.23 \mathrm{mg} / \mathrm{kg}$. That value may increase up to $1.505 \mathrm{mg} / \mathrm{kg}$ in urbanized areas (GEBEL et al. 1996), while sheep receiving seaweed (containing arsenosugar) cumulate even $13.03 \mu \mathrm{g} / \mathrm{g}$ of this element ( 7.08 on average) in fibre, and only $1.86 \mu \mathrm{g} / \mathrm{g}$ in lanolin (RAAB et al. 2002).

Table 3

Content of heavy metals in sheep wool from Poland, Greece and Syria $(\mathrm{mg} / \mathrm{kg})$

Gehalt an Schwermetallen in Schafwollen ( $\mathrm{mg} / \mathrm{kg}$ )

\begin{tabular}{llll}
\hline Element & \multicolumn{1}{c}{ Poland } & \multicolumn{1}{c}{ Greece } & \multicolumn{1}{c}{ Syria } \\
\hline Arsenic $(\mathrm{As})$ & $0.233^{\mathrm{b}} \pm 0.055$ & $0.206^{\mathrm{b}} \pm 0.046$ & $0.765^{\mathrm{a}} \pm 0.249$ \\
Cadmium $(\mathrm{Cd})$ & $0.134 \pm 0.032$ & $0.342 \pm 0.14$ & $0.294 \pm 0.112$ \\
Mercury $(\mathrm{Hg})$ & $0.010^{\mathrm{a}} \pm 0.002^{*}$ & $0.024 \pm 0.021$ & $0.081^{\mathrm{b}} \pm 0.056$ \\
Lead $(\mathrm{Pb})$ & $2.59 \pm 1.34$ & $2.32 \pm 0.65$ & $2.46 \pm 0.85$ \\
\hline $\mathrm{a}, \mathrm{b}, \mathrm{c} P<0.05, \quad{ }^{*}$ one sample below the detection treshold of $0.2 \mathrm{ng} / \mathrm{g}$ & &
\end{tabular}

Cadmium (Cd) concentration ranged from 0.134 to $0.342 \mathrm{mg} / \mathrm{kg}$. The highest amount of this element was found in W-Gr, while the lowest one in W-PI (differences insignificant 
statistically). Some authors (ENNE et al. 1989, KOŁACZ et al. 1999, PATKOWSKA-SOKOŁA et al. 2003, AYDIN 2008) report a relatively wide range of Cd concentration, i.e. from 0.0186 to $1.8 \mathrm{mg} / \mathrm{kg}$.

Mercury $(\mathrm{Hg})$ concentration ranged from 0.010 to $0.081 \mathrm{mg} / \mathrm{kg}$. The highest amount of this element was noted in the case of W-Sy, and the lowest one in W-PI $(P<0.05)$. BODKOWSKI et al. (2006) observed an average concentration of $\mathrm{Hg}$ in the region of copper industry at the level of 0.19 ppm, GEBEL et al. (1996) reported an average $\mathrm{Hg}$ content in sheep wool of only $0.107 \mathrm{mg} / \mathrm{kg}$ in the area affected by mercury mines in Germany. It is known that mercury is available mainly in an organic form (KABATAPENDIAS and PENDIAS 1999).

Lead $(\mathrm{Pb})$ concentration was within the range of 2.32 to $2.59 \mathrm{mg} / \mathrm{kg}$. Its highest amount were found in W-PI, and the lowest ones in W-Gr (differences insignificant statistically). Numerous authors (ENNE et al. 1989, KOŁACZ et al. 1999, PATKOWSKASOKOŁA et al. 2003, BODKOWSKI et al. 2006, AYDIN, 2008) report a wide concentration range of this toxic element, i.e. $0.015-6.94 \mathrm{mg} / \mathrm{kg}$.

The results obtained from this research are difficult to interpret unequivocally. Except for $\mathrm{K}$, other bioelements ( $\mathrm{Ca}, \mathrm{P}, \mathrm{Na}, \mathrm{Mg}$ and $\mathrm{S}$ ) did significantly differ between the groups (countries). Special attention should be paid to the 5-fold higher Mg concentration in W-Sy as to compare to W-PI. It seems that such a high variability of macroelements content in the analysed samples may be due to nutritional and biogeochemical background. Only detailed analysis of the mineral composition of soil, water and feed could provide the answer, e.g. for the reason of especially high concentration of $\mathrm{Al}, \mathrm{Fe}$, Ti or As in the wool from Syria as compared to $\mathrm{W}-\mathrm{PI}$ or $\mathrm{W}-\mathrm{Gr}$. The different values of the proportional content of the main elements, i.e. $\mathrm{Ca} / \mathrm{P}, \mathrm{Na} / \mathrm{K}, \mathrm{Cu} / \mathrm{Zn}, \mathrm{Fe} / \mathrm{Mn}, \mathrm{Cu} / \mathrm{Mo}$ in particular groups (Table 4) is noteworthy. Except for $\mathrm{S}, \mathrm{Ca}$, Na and $\mathrm{K}$, the order of descending values is different, and at the end of this sequence there are three heavy metals, As, Cd and Hg, in all groups (W-Sy, W-PI and W-Gr) (Table 5). In the case of As and $\mathrm{Hg}$ the highest concentration in W-Sy was observed, which is also difficult to explain without a biomonitoring investigation on their habitat. $\mathrm{Cd}$ and $\mathrm{Pb}$, however, did not differ significantly between the analysed wool samples.

Table 4

Accumulation coefficients of main chemical elements in sheep wool from Poland, Greece and Syria Kumulationskoeffizient der wichtigsten chemischen Elemente in Schafwollen

\begin{tabular}{lllllr}
\hline Country & $\mathrm{Ca} / \mathrm{P}$ & $\mathrm{Na} / \mathrm{K}$ & $\mathrm{Cu} / \mathrm{Zn}$ & $\mathrm{Fe} / \mathrm{Mn}$ & $\mathrm{Cu} / \mathrm{Mo}$ \\
\hline Poland & 12.09 & 2.07 & 0.06 & 6.54 & 5.41 \\
Greece & 14.08 & 3.37 & 0.09 & 17.31 & 10.45 \\
Syria & 6.34 & 2.31 & 0.14 & 22.38 & 4.46 \\
\hline
\end{tabular}

Table 5

Concentration of analysed elements in the wool from Poland, Greece and Syria in a descending order of values Konzentration untersuchter chemischer Elemente in Wollen in absteigender Reihenfolge der Gehaltswerte

Element

\begin{tabular}{lllllllllllllllllllll} 
& 1 & 2 & 3 & 4 & 5 & 6 & 7 & 8 & 9 & 10 & 11 & 12 & 13 & 14 & 15 & 16 & 17 & 18 & 19 & 20 \\
\hline Poland & $\mathrm{S}>\mathrm{Ca}>\mathrm{Na}>\mathrm{K}>\mathrm{P}>\mathrm{Mg}>\mathrm{Zn}>\mathrm{Al}>\mathrm{Fe}>\mathrm{Cu}>\mathrm{Mn}>\mathrm{Sr}>\mathrm{Pb}>\mathrm{Ba}>\mathrm{Mo}>\mathrm{Co}>\mathrm{Ti}>\mathrm{As}>\mathrm{Cd}>\mathrm{Hg}$ \\
Greece & $\mathrm{S}>\mathrm{Ca}>\mathrm{Na}>\mathrm{K}>\mathrm{Mg}>\mathrm{P}>\mathrm{Al}>\mathrm{Fe}>\mathrm{Zn}>\mathrm{Sr}>\mathrm{Cu}>\mathrm{Mn}>\mathrm{Ba}>\mathrm{Ti}>\mathrm{Pb}>\mathrm{Mo}>\mathrm{Co}>\mathrm{Cd}>\mathrm{As}>\mathrm{Hg}$ \\
Syria & $\mathrm{S}>\mathrm{Ca}>\mathrm{Na}>\mathrm{K}>\mathrm{Al}>\mathrm{Mg}>\mathrm{Fe}>\mathrm{P}>\mathrm{Zn}>\mathrm{Ti}>\mathrm{Mn}>\mathrm{Sr}>\mathrm{Cu}>\mathrm{Ba}>\mathrm{Pb}>\mathrm{Co}>\mathrm{Mo}>\mathrm{As}>\mathrm{Cd}>\mathrm{Hg}$ \\
\hline
\end{tabular}




\section{References}

Antunovic Z, Speranda M, Steiner Z (2004) The influence of age and the reproductive status to the blond indicators of the ewes. Arch Tierz 47, 265-73

Aydin I (2008) Comparison of dry, wet and microwave digestion procedures for the determination of chemical elements in wool samples in Turkey using ICP-OES technique. Microchemical J 90, 82-7

Baranowski P (2002) Genetic and environmental factors of macrolelements concentration in blood serum and osseous tissue of lambs in north-west Poland. Arch Tierz 45, 565-74

Baranowski P, Klata W, Baranow-Baranowski S (2004) Macroelements concentration in the osseous tissue of cadual vertebeae in domestic sheep lambs and of mandibular bone in roe deer bucks coming from the northern and the southern region of Western Pomerania in Poland. Arch Tierz 47, 75-84

Bodkowski R, Patkowska-Sokoła B, Dobrzański Z, Janczak M, Zygadlik K (2006) Exploitation of sheep wool for an assessment of environmental pollution with heavy metals. Roczn Nauk PTZ 2, 105-11 [in Polish]

Castillo C, Hernandez JR, Lopez M, Miranda M, Garcia-Partida, P, Benedito JL (1997) Relationship between venous $\mathrm{pH}$, serum calcium and proteins in the course of anoestrus, pregnancy and lactation in the ewe. Arch Tierz 40, 257-63

Enne G, Leita L, Giardini I, Sequi P (1989) Relationship between the level of environmental contamination with heavy metals and their accumulation in sheep tissues. Medycyna Wet 9-10, 565-8

Gabryszuk M, Klewiec J, Czauderna R, Baranowski A, Kowalczyk J (2000) The content of mineral compounds in sheep wool depending on the breed and physiological state. Rocz Nauk Zoot Suppl 5, 147-51 [in Polish]

Gallo M, Gallo J, Sommer A, Flak P (1996) Influence of emission fall-out movement of heavy metals in the cycle soil, plant, animal. Arch Tierz 39, 195-202

Gebel T, Kevekordes S, Schaefer J, Von Platen H, Dunkelberg H (1996) Assessment of possible genotoxic environmental risk in sheep bred on grounds with strongly elevated contents of mercury, arsenic and antimony. Gen Toxicol 368, 267-74

Georgievski VI, Annenkov BN, Samokhin VT (1982) Mineral Nutrition of Animals. Butterworths, London, 91-222

Huang Y, Chen $\mathrm{H}$ (2001) Studies on the pathogenesis of Shimao Zheng (fleece-eating) in sheep and goats. Vet Res Com 25, 631-40

lyengar GV (1998) Reevaluation of the trace element content in reference man. Radiat Phys Chem 51, $545-60$

Johnsson C, Sällsten G, Schütz A, Sjörs A, Barregård L (2004) Hair mercury levels versus freshwater fish consumption in household members of Swedish angling societies. Environ Res 96, 257-63

Kabata-Pendias A, Pendias H (1999) Bioeochemistry of trace elements. Wyd Nauk PWN Warszawa [in Polish]

Kołacz R, Bodak E, Dobrzański Z, Patkowska-Sokoła B (1999) Trace elements in the wool of Polish merino sheep grazed in polluted and unpolluted environment. Czech J Anim Sci 44, 509-14

Krośnicka-Bombała R (1996) Influence of a season of the year and a colour on pigment and microelements content in a coat of differently coloured sheep and goats. Zesz Nauk Przeg Hod PTZ 23, 117-32 [in Polish]

Patkowska-Sokoła B (1990) Investigations on effects of elemental sulphur (35S; S0) administration to Merino Sheep. Zesz Nauk AR Wrocław Rozpr Habil 83 [in Polish]

Patkowska-Sokoła B, Dobrzański Z, Bodak E, Panyiotu P, Kołacz R (2003) Comparative study on the concentration of elements in the wool of sheep of Cyprus and Poland origin. Chem Agric 4, 182-9

Pors Nielsen S (2004) The biological role of strontium. Bone 35, 583-8

Raab A, Hansen HR, Zhuang L, Feldman J (2002) Arsenic accumulation and speciation analysis in wool from sheep exposed to arsenosugars. Talanta $58,67-76$

Ramirez-Perez AH, Buntinx SE, Rosiles R (2000) Effect of breed and age on voluntary intake and the micromineral status of non-pregnant sheep. Micromineral status. Small Rumin Res 37, 231-42

Scott G (1991) The Sheepman's Production Handbook, 4th ed Abegg Printing, USA

Sztych D, Soroczyńska M (1994) Some chosen macro- and microelements in the wool of sheep in different stages of lactation. Ann Warsaw Agricult Univ - SGGW, Anim Sci 32, 47-53 
Wojcikowska SM, Sztych D (1994) Selected microelements in wool of Polish sheep. Ann Warsaw Agricult Univ 30, 59-68

Żarski TP (1988) A recognition and an assessment of different methods of prevention and liquidation of mineral deficiencies in domestic and wild ruminants. SGGW-AR, Warszawa [in Polish]

Received 8 January 2008, accepted 2 May 2009.

Corresponding author:

Prof. Dr. BOŻENA PATKOWSKA-SOKOŁA

email: bozena.patkowska-sokola@up.wroc.pl

Institute of Animal Breeding, Wroclaw University of Environmental and Life Sciences, Chelmonskiego 38c, 51-630 Wroclaw, Poland 